$\xi=-1$

\title{
The effect of interpersonal communication skills and work motivation on performance of marketing employee
}

\author{
Nana Herdiana Abdurrahman * \\ ${ }^{1}$ UIN Sunan Gunung Djati Bandung \\ *Corresponding author E-mail: nanaherdiana@ uinsgd.ac.id
}

\begin{abstract}
To improve and maintain the performance of the marketing department employee, the company should improve the capacity and capability of the employees. This research aimed to investigate the influence of interpersonal communication and work motivation on employee performance marketing. This research uses a quantitative approach method with path analysis method. This study uses survey technique with the primary data collection tool in the form of a questionnaire. The study was conducted at the Jabar Banten Shariah Bank Bandung branch, with respondents as many as 33 people. The test results show that partial and or simultaneously, interpersonal communication and work motivation have significant positive effect on employee performance. The results show that the value of the determinant obtained for 0808, this means that the variables of interpersonal communication and motivation can explain the employees' performance by $80.0 \%$, while $19.2 \%$ is influenced by other variables that are not included in the model. Epsilon factors are leadership, organizational culture, facilities and infrastructure in the works, and others. The result show that performance of the marketing department can be improved through the development of interpersonal communication capacity of employees and strengthening of motivation to work.
\end{abstract}

Keywords: Interpersonal Communication Skills; Motivation; Employee Performance

\section{Introduction}

\subsection{Research Background}

Sharia banking is part of sharia economics so sharia banking cannot be separated from the Quran and the Sunnah as the source of Islamic law. Sharia banking also cannot be separated from the sharia economics paradigms. Sharia and conventional banking run the same function which is to be the intermediary institution for the customers who has capital with clients who need financing. However, the customers who have money in a sharia bank are treated like investors. The money collected by sharia bank is channeled to the clients who needs financing in their various needs both productive needs and consumptive needs. From the financing, sharia bank will earn a profit sharing margin/ income for itself. The customers will have to pay the installment of the profit sharing margin to the sharia bank with the amount that both parties have agreed together.

Many people still do not understand the products and the system of sharia bank. However, it is one of the growing industries, and it will not match with the growth of Indonesian population that are mostly Muslim. The data of the market share of Bank Jabar Banten Sharia compared to both other conventional banks, and other sharia banks are as follows.
Table 1: Total asset possessed by the Bank Jabar Banten Shariah compared to other conventional banks in Indonesia in billions Rupiah

\begin{tabular}{|l|l|}
\hline Assets & December 2010 \\
\hline Conventional bank & $3,008,853$ Trillion \\
\hline Bank BJBS & 19 billion \\
\hline Market share & $0,00064 \%$ \\
\hline
\end{tabular}

Source: Statistics by Bank of Indonesia

Based on the table above it is found out that the market share of Bank Jabar Banten Sharia compared to other conventional banks in Indonesia in 2010 is only $0,00064 \%$.

Table 2: Total asset possessed by Bank Jabar Banten Sharia compared to other shariah banks in Indonesia in Billion

\begin{tabular}{|c|c|}
\hline Assets & December 2015 \\
\hline Shariah bank & 97,519 \\
\hline Bank BJBS & 19,3 \\
\hline Market share & $0,020 \%$ \\
\hline
\end{tabular}

Source: Statistics by Bank of Indonesia

Based on the table above it is shown that the market share of Bank Jabar Banten Sharia compared to another sharia bank in Indonesia in 2015 is $0,020 \%$.

The reason why someone saves or deposits in sharia bank is often due to the guilt they feel when saving in the conventional bank because it is against Islamic values. Another reason is that sharia business is considered to be more promising compared to nonsharia. Thus, many customers move to sharia banks with its just and efficient profit sharing system. These two reasons can be considered to represent the two potential markets of sharia banks, the emotional and spiritual market, and rational market.

The emotional and spiritual market is the majority of Muslims. Because of their firm, or even fanatic, belief, they choose sharia 
bank. It can be said that they are the captive market for sharia banking. Meanwhile, the rational market is the customers who use rational considerations. They will choose sharia bank if it is financially more profitable. The rational market is not reached well yet. They lack the interest in sharia business because it is identical with religion (Islam). Thus, they think the opportunity of sharia market is closed to the non-Muslim. While, in fact, the profit sharing in sharia market has been widely used in European countries, especially in England, for so long. There are still many people who do not know that the main principle of sharia is very universal, namely the goodness and justice for all.

Considering the condition described above, Bank BJBS needs to increase the quantity and the quality of its marketing to achieve the optimized market share. This increase will lead to a sustainable profit. Besides the need to improve and empower communication, BJBS also needs to grow and empower its employees, so it will boost the financial and non-financial performance.

Therefore, this study aimed to find (a) the influence of interpersonal communication skill to the performance of BJBS marketing department employees, (b) influence of work motivation on the performance of BJBS marketing department employees, and (c) the influence of interpersonal communication skill and work motivation simultaneously on the performance of BJBS marketing department employees.

Below is the framework to measure the influence of interpersonal communication skill, and work motivation on the performance of BJBS marketing department employees.

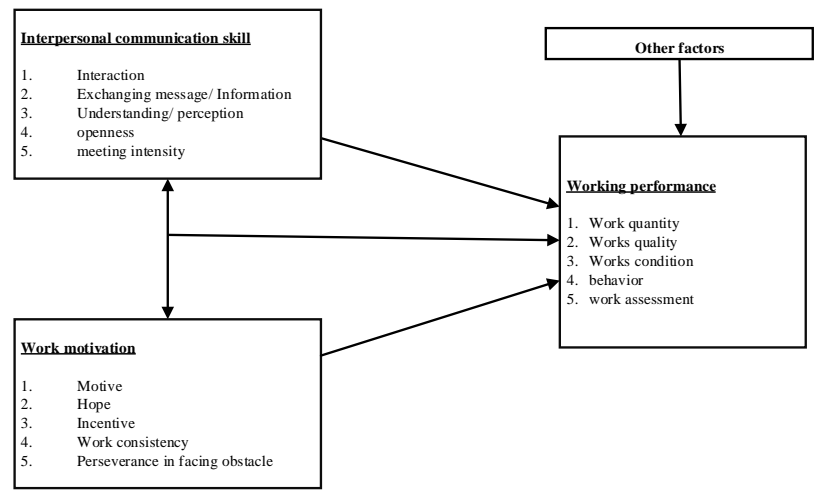

Fig 1: Framework

\section{Literature Review}

\subsection{Interpersonal communication skill}

Robbins and Judge (2009) stated that every individual has the strengths and weaknesses in skill particular skill that make him superior or inferior compared to other people in doing certain task or activity. Still, according to Robbins and Judge, the whole skill of a person is mainly divided into two certain factors, namely:

1. The mental skill is the skill needed to perform various mental activities: thinking, reasoning, and problem-solving. Individuals in most societies put intelligence, for a good reason, in the highest place. Intelligent people usually earn more money and have higher education. They also probably become the leader of one group. Seven dimensions that form intellectual ability are namely numerical, verbal, perception, inductive reasoning, deductive reasoning, different visualization, and memory.

2. Physical ability is the capacity to perform activities and tasks that demand stamina, creativity, strength and similar characteristics. There are various requirements needed in hundreds of jobs to be able to identify nine basics skills including in the performance of physical task: dynamic, body, static, explosive strength, extensive flexibility, flexibility, body coordination, balance, stamina

The performance of an employee will probably increase when the management can define how high a job need the level of each ability. Different jobs require different skills. The performance of an employee will increase if there is a high job-ability suitability. Interpersonal communication is a very practical art, useful in gaining a relationship with business partners, work colleagues, including on the managerial level that needs interpersonal communication.

Meanwhile, some scholars believe that interpersonal and communication are a separate skill. Communication skill is the ability to perform a particular task that can be measured. Meanwhile, the interpersonal skill is an inherent relationship based on the process of communication (1). Another research suggests a significant role of emotional intelligence in building interpersonal communication skill (2). Those who have high emotional intelligent also deem to have high score in performance (3). However, emotional intelligent is not the only determinant factor in employees' performance. Other factor such as organizational culture also play an important role in defining their performance (4-6).

\subsection{Motivation}

The definition of motivation varies related to individual behavior and organizational behavior.Colquitt and Wesson (7) defined it as a set of impulses or energies that come both from internal sources and external sources that are related to starting an effort or deciding the path. Motivation is the significant predictor of successful working life (8). Moreover, there is research that proves the correlation between decreased work motivation and increased depression (9). People have different motivation in doing work. Their motivations are heavily influenced by the condition surrounding their work (10). Motivation, along with experience and competence, is a crucial factor in predicting performance (11).

\subsection{Performance}

George and Jones (12) saw the performance as something related to:" the thought and feeling of people have about work, their jobs, and their organizations, determine how they experience work. Some ideas and feelings are fundamental and broad; they are concerned not so much with aspects of a particular job or organization but more with the meaning and nature of work itself. These thoughts and feelings are more specific." The mood of mind and feeling of employees will determine the behavior in work. The neighborhood condition will affect what to do is valuable or not. The work done on such condition will result in the possibility of a much wider work result. Furthermore, the employee's perception on the organizational politics also has an effect on their performance (13).

\section{Methodology}

\subsection{The methods}

By the research goals, the methods used in this study were descriptive and verifying methods.

The descriptive research aims to have the description about the nature and characteristics of the variables studied, while verifying method seeks to know and analyze the relationship between variables through data gathering in the field. Thus, the methods used in this research were a descriptive survey and explanatory survey.

\subsection{Variable operationalization}

In this research, there are two independent variables which are the interpersonal communication skill (x), and motivation (X2), and one dependent variable which is the employee performance $(\mathrm{Y})$. The operational definition of each variable is as follows:

a) The interpersonal communication skill is interaction among individuals or group in various messages and information openly to obtain common understanding/ perception regarding one meaning. 
b) Work motivation is the impulses, willingness, and the level of desire of a person to release all efforts to achieve a a good job result.

c) The employee performance is the show of work of an individual in doing his tasks.

\subsection{Data gathering method}

This research used quantitative approach using survey method. It means the study to know and define the level of a variable (status quo variable)

\section{a) Instrument testing}

1. Validity test

A validity test of the device used to measure the study variables needs to be done first before analyzing the fundamental problem. To test the validity of measuring tool, the study used Person Product Moment formula existing in SPSS. The formula is as follows:

$$
r_{y x}=\frac{n\left(\sum x y\right)-\left(\sum x\right)\left(\sum y\right)}{\sqrt{\left\{n\left(x^{2}\right)-\left(\sum x\right)^{2}\right\}\left\{n\left(\sum y^{2}\right)-\left(\sum y\right)^{2}\right\}}}
$$

Where:

$\mathrm{r} \mathrm{yx}=$ correlation of product moment

$\mathrm{x}=$ score per item in a variable

$\mathrm{y}=$ item total score in a variable

$\mathrm{n}=$ the number of respondents

\section{Reliability test}

If the measuring tool is proven to be valid, then the measuring tool is tested its reliability. If the coefficient is $>0.600$, it indicates that the reliability consistency of the measuring tool is good. The reliability testing method used is Cronbach's Alpha. The formula is as follows:

$$
\mathrm{r}=\frac{\mathrm{k}}{\mathrm{k}-1}\left\{1-\frac{\sum \mathrm{s}_{\mathrm{i}}^{2}}{\mathrm{~s}_{\mathrm{t}}^{2}}\right\}
$$

Where:

$r=$ Cronbach's Alpha coefficient

$\mathrm{k}=$ the number of items

$$
\begin{array}{ll}
\sum \mathrm{s}_{\mathrm{i}}^{2} & =\text { the number of item variants } \\
\mathrm{s}_{\mathrm{t}}^{2} & =\text { total variant }
\end{array}
$$

While the whole variant formula and item variant are as follows:

$$
\begin{aligned}
& s_{t}^{2}=\frac{\sum X_{t}^{2}}{n}-\frac{\left(\sum X_{t}\right)^{2}}{n^{2}} \\
& \sum s_{t}^{2}=\frac{J K_{i}}{n}-\frac{J K_{s}}{n^{2}}
\end{aligned}
$$

Where:

$\mathrm{JK}_{\mathrm{i}} \quad=$ the number of total item score quadrat

$\mathrm{JK}_{\mathrm{s}}=$ the number of subject quadrat

\section{Normality testing}

Data normality test is the primary requirement in the parametric analysis because the data that will be analyzed must normally be distributed. In the normality test sample, if it is found the result of the test to be 0.000 or smaller than the level of trust determined, for example, 0.05, then this number shows that the data sample is normally distributed.

\section{Linear regression test}

A Linear regression test is a requirement before analyzing correlation. Two variables can be said to have linear relationship if the significance in the linearity is less than 0.05

\section{Multicollinearity test}

Multicollinearity test is used to test why it is found a correlation between dependent variables in the regression model. If the value of VIF is less than 10 and the tolerance is less than 0.1 , then the regression model is free from multicollinearity.

\section{Autocorrelation test}

Autocorrelation is a correlation between the members of observation arranged according to the timeline like in time series data or order of place/room data, or relationship emerged from itself. The measurement used to test whether autocorrelation exists if the value of Durbin-Watson statistic is close to 2 . If it is close to 2 , then the data has no autocorrelation.

\section{Heteroskedasticity test}

This test is used to test whether the regression happened a different variant from the residuals of other observation.

\section{b) Data analysis technique}

In data analysis method, if the data needed has been gathered, the next step is to analyze the data. The data analysis technique used in this research was as follows:

\section{a. Multiple linear regression}

The model of variable relation was analyzed according to the regression equation with the following multiple regression equation formulae.

$\mathrm{Y}=\mathrm{a}+\mathrm{b}-\mathrm{X}_{2}+\mathrm{b}_{2} \mathrm{X}_{2}$

With the following description:

$\mathrm{Y}=$ dependent variable

$\mathrm{X}_{1}, \mathrm{X}_{2} \quad=$ independent variable

$\mathrm{a}=$ constant

$\mathrm{b}_{1}, \mathrm{~b}_{2} \quad=$ Regression coefficient

b. $\quad$ test

F test is a tool to test independent variable simultaneously with other dependent variables. The criteria of test using $\mathrm{F}$ test is as follows:

1. If $\mathrm{F}$ value is $>$ Table $\mathrm{F}$, it means there is a common influence from all independent variable toward dependent variables.

2. If $\mathrm{F}$ value is < Table $\mathrm{F}$, it means there is no common influence from all independent variables toward dependent variables.

\section{c. t-Test}

$\mathrm{t}$ Test aims to know whether a partially independent variable has influence significantly to the dependent variables, with the assumption that other independent variables is constant. The steps to do the test is as follows:

1. Determining the hypothesis

Ho: $\mathrm{B}=0 ; \mathrm{B}_{2}=0$ (independent variable as individual has no significant influence on dependent variables)

$\mathrm{H}, \mathrm{b}-{ }^{-*} \mathrm{O} \sim \mathrm{b}_{2} * " 0$ (independent variable as individual has significant influence on dependent variable)

2. Level of significance is $5 \%$ or a $=0.05$

3. Testing criteria

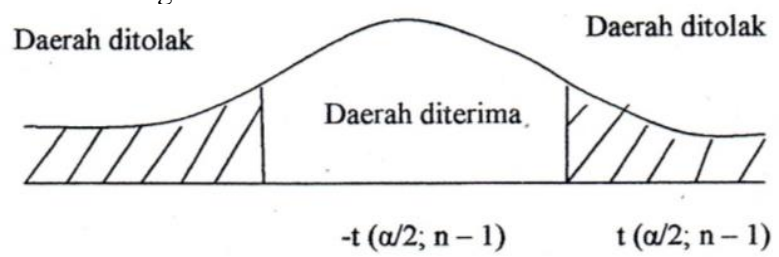

4. T-value calculation

$\mathrm{t}$ value $=(b-\beta) \div S e$

Where:

b = variable regression coefficient

Se = standard error of variable regression coefficient

$\mathrm{B}=$ Beta coefficient

5. Conclusion

Ho is accepted if table -t: St count: $\mathrm{S}$ Table $\mathrm{t}$

Ho is rejected if table $\mathrm{t}<-\mathrm{t}$ count or table $\mathrm{t}>\mathrm{t}$ count

\section{d. $\quad \mathbf{R}^{\mathbf{2}}$ (determinant coefficient)}

It is used to know how the independent variables can explain much variants from the dependent variable. $R$ used in this study is $\mathrm{R}$ that considers the number of variable independent in a model, or it can be called adjusted R. Determinant coefficient adjusted $R$ shows the percentage of total variation from the dependent variables that can be explained by independent variable in the model. $\mathrm{R}^{2}$ value shows that variation of dependent variables can be explained by the variation of the independent variable. Likewise, if the $\mathrm{R}^{2}$ is close to 0 , then the variation from dependent variable cannot be explained by the independent variable. 


\section{Results and Findings}

\subsection{Instrument testing}

1) Validity test

The validity test shows that all $\mathrm{t}$ values is greater than $\mathrm{t}$ table which is 0.344 in the significance level of $5 \%$. It means every statement is correlated with the total score and the data gathered is considered valid and ready to be analyzed.

2) Reliability test

The reliability test is used to know how much a measuring tool can be trusted or reliable and remain consistent if two measurements are done or more to the same group with the measuring tool.

Table 3: Reliability Test Result

\begin{tabular}{|l|c|c|}
\hline \multicolumn{1}{|c|}{ Variables } & Alpha & \multirow{2}{*}{ Explanation } \\
\cline { 2 - 3 } & Coefficient & Reliable \\
\hline $\begin{array}{l}\text { Interpersonal Communication } \\
\text { Skill }\end{array}$ & 0,893 & Reliable \\
\hline Work motivation & 0,900 & Reliable \\
\hline Employees' performance & 0,839 & \\
\hline
\end{tabular}

Source: analyzed data

The reliability test result in reliability coefficient value which is greater than 0,6. According to Ghozali (2005), it is considered that all the statement in the questionnaire is reliable.

a. Data analysis

1) Normality test

Normality test in this study is used to determine whether the data is normally distributed. To test the normality of data, the study used Kolmogorov-Smirnov. Then, to accept or reject the hypothesis, the study compare the $\mathrm{p}$-value with the level of significance (a) 0.05 . If $p$-value $>0.05$, then the data is normally distributed. The result from normality test can be observed in Appendix 9 and is briefly shown on the table 4.9.

Table 4: The Result of Data Normality Test

\begin{tabular}{|c|c|c|c|c|}
\hline \multirow{2}{*}{ Variable } & \multicolumn{2}{|c|}{ Kolmogorov-p-value } & \multirow{2}{*}{ Sig } & \multirow{2}{*}{ Status } \\
\hline & Smirnov & & & \\
\hline Unstandardized & 0.403 & 0.997 & $\mathrm{P}>0.05$ & Normal \\
\hline Residual & & & & \\
\hline
\end{tabular}

Source: analyzed data

From the calculation of Kogomorov-Smirnov test, it can be determined that $\mathrm{p}$-value from unstandardized residual is bigger than a $(\mathrm{p}>0.05)$, so the whole data is considered to have normal distribution.

2) Regression linearity test

Linearity test is pre-requirement that is usually needed before analyzing correlation. This test aims to determine whether two variables have significant linier relation or not. To test the linearity on SPSS, the study used linearity test with 0.05 significance. Two variables can be determined to have a linear relationship if the significance on linearity is less than 0.05. The result from linear regression can be seen in Appendix 10 and is briefly shown in Table 4.10.

Table 5: The Result of Linear Regression Test

\begin{tabular}{|c|c|c|}
\hline Variable & Sig & Status \\
\hline Interpersonal communication skill & 0,000 & Linear \\
\hline Work motivation & 0,001 & Liniar \\
\hline
\end{tabular}

Source: data analyzed

The result from the linearity test can be seen from the ANOVA output table. It can be determined that the significance value of Interpersonal Communication Skill is 0.000 and work motivation is 0.001 . Because the significance is less than $0.05(0.001<0.05)$ between interpersonal communication skill and work motivation, has linear relationship toward the employees' performance.

3) Multicollinearity test

Multicollinearity test was used to determine whether there is a correlation between independent variables. The result of multicollinearity can be seen from the number of Tolerance Value and Variance Inflation Factor (VIF).
Table 6: The Result of Multi Collinearity Test

\begin{tabular}{|l|c|c|c|}
\hline \multicolumn{1}{|c|}{ Variable } & Tolerance & VIF & Explanation \\
\hline $\begin{array}{l}\text { Interpersonal Commu- } \\
\text { nication skill }\end{array}$ & 0,326 & 3,068 & Multi collinearity free \\
\hline & & & \\
\hline Work Motivation & 0,326 & 3,068 & Multi collinearity free \\
\hline
\end{tabular}

Source: data analyzed

4) utocorrelation test

Autocorrelation test was used to test whether regression model has a correlation with the residual on period $t$ with residual on past period (t-1). The testing method used Durbin-Watson. The decision of using Durbin-Watson test is as follows:

a. $d u<d w<4-d u$ then Ho is accepted, it means there is no autocorrelation.

b. $\mathrm{dw}<\mathrm{dl}$ or $\mathrm{dw}>4-\mathrm{dl}$ then Ho is rejected, it means there is auto correlation.

c. $\mathrm{dl}<\mathrm{dw}<\mathrm{dl}$ or $4-\mathrm{du}<\mathrm{dw}<4-\mathrm{dl}$, it means there is no certainty or certain conclusion.

Table 7: The Result of Auto Correlation Test

\begin{tabular}{|l|l|}
\hline Durbin-Watson Value & Explanation \\
\hline 2.006 & There is no auto correlation \\
\hline
\end{tabular}

Source: data analyzed

Durbin-Watson value can be seen from the regression output on the model summary table. It can be determined the Durbin-Watson value of 2.006. While from the DW table with the significance of 0.05 from the number of data $(n)=33$, and $\mathrm{k}=2(\mathrm{k}$ is the number of the independent variables) it was obtained the value of 1.1321 and du value of 1.577 (it can be seen in Appendix 26). Thus, it equals $4-\mathrm{du}=2.324$ and $4-\mathrm{dl}=2.679$. Because $\mathrm{DW}$ value is in the region between $d u$ and 4 -duu $(d u<d w<4-d u)$, then Ho is accepted. Thus, it can be concluded that there is no autocorrelation in the regression model.

5) Heteroskedasticity test

Heteroskedasticity test was used to determine whether in a regression model there is the same variation (homoscedasticity) from the residual to other observation.

Table 8: The Result of Heteroskedasticity Test

\begin{tabular}{|l|l|l|}
\hline Variable & sig & Explanation \\
\hline $\begin{array}{l}\text { Interpersonal commu- } \\
\text { nication skill }\end{array}$ & 0.757 & No heteroskedasticity \\
\hline Work motivation & 0.822 & No heteroskedasticity \\
\hline
\end{tabular}

The table above shows that correlation between two variables with unstandardized residual significant value is more than 0.05 so it can be determined that there is no heteroscedasticity in the regression model.

6) Multiple linear regression analysis

Regression analysis in this study was used to test the influence of interpersonal communication and work motivation toward employees' performance. The result is as follows:

Table 9: The Result of Multiple Linear Regression Analysis

\begin{tabular}{|l|c|}
\hline Variable & Coefficient \\
\hline Constant & -3.869 \\
\hline $\begin{array}{l}\text { Interpersonal communication } \\
\text { skill }\end{array}$ & 0.315 \\
\hline Work motivation & 0.236 \\
\hline
\end{tabular}

Source: data analyzed

From the regression analysis result above, it can be formulated the following equation:

$\mathrm{KK}=-3.869+0.315 \mathrm{KKI}+0,236 \mathrm{MK}$

The above equation shows that employee's performance is influenced by their interpersonal skill and their work motivation. The following is the detail explanation:

a. The constant value is -3.869 it means if there is no increase in interpersonal communication skill, and work motivation, the performance score will be smaller or 3.869 unit.

b. The variable regression coefficient value of interpersonal communication value is 0.315 ; it means if there is an increase in interpersonal communication skill as 1 unit, then the employees' performance will increase as much as 0.315 unit. 
c. The regression coefficient value of work motivation variable is -0.236 . It means if there is an increase in work motivation as 1 unit, then the performance will increase as much as 0.236 unit.

7) F Test

It was used to verify the independent variable influence simultaneously toward dependent variable.

The steps in doing $\mathrm{F}$ test is as follows:

a. Formulating hypothesis

Ho: Interpersonal communication skill and work motivation together do not influence the employee's performance.

Ha: Interpersonal communication skill and work motivation together do not influence the employees' performance.

b. Determining the level of significance of 0.05

c. Determining F count. Based on SPSS output the F count was obtained as 63.057 (see Appendix 13)

d. Determining F table. With the level of $95 \%$ certainty, $a=5 \%$, df 1 (the number of variable -1 ) or $3-1=2$ and df 2 (n-k-1) or $33-2-1=30$ ( $\mathrm{n}$ is the number of data and $\mathrm{k}$ the number of independent variable). The result shows that $\mathrm{F}$ table is 4.171 (see Appendix 24)

e. Testing criteria

1. Ho is accepted if F count: S F table

2. Ho is rejected if $\mathrm{F}$ count $>\mathrm{F}$ table

f. Comparing $f$ count with $f$ table. Because $f$ count $>\mathrm{f}$ table $(63.057>4.171)$, then Ho is rejected. It means interpersonal communication skill and work motivation together influence employees' performance.

8) Hypothesis test (t-test)

Hypothesis test in this study used t-test (partial regression coefficient test)

Table 10: t-Test Result

\begin{tabular}{|l|c|c|c|}
\hline \multicolumn{1}{|c|}{ variable } & t count & t table & Explanation \\
\hline $\begin{array}{l}\text { Interpersonal } \\
\text { communication } \\
\text { skill }\end{array}$ & 3.611 & 2.042 & $\begin{array}{c}\text { Ho is } \\
\text { rejected }\end{array}$ \\
\hline $\begin{array}{l}\text { Work motiva- } \\
\text { tion }\end{array}$ & 3.106 & 2.042 & $\begin{array}{c}\text { Ho is } \\
\text { rejected }\end{array}$ \\
\hline
\end{tabular}

Source: data analyzed

a. Determining $\mathrm{t}$ table. $\mathrm{t}$ distribution table was searched on (1 $=5 \%: 2=2,5 \%$ (two sides test) with freedom limit (df) n-kI or $33-2-1=30$ ( $\mathrm{n}$ is the number of data and $\mathrm{K}$ is the number of independence variables). With two sides test (significance $=$ 0.025 ), the result obtained for table $t$ is 2.042 (see Appendix 23)

b. Testing criteria

1. Ho is accepted if $-t$ table $\sim t$ count $s$ table $t$

2. Ho is rejected if $-t$ count $<-t$ table. Because the value of $t$ count $>$ t table $(3.611>2.042$ for interpersonal communication skill and $3.106>2.042$ for work motivation), thus, Ho is rejected. It means that interpersonal communication skill and work motivation is partially influential to the employees' performance.

9) Determinant coefficient $\left(\mathrm{R}^{2}\right)$

The test conducted results in a coefficient value of determinan $\mathrm{R}^{2}$ of 0.0808 . Thus, it can be determined that result of the test is a good fit. It shows that $80.8 \%$ employees' performance variation can be explained by their interpersonal communication skill and work motivation. Meanwhile, $19.2 \%$ can be explained by other variables outside of the model.

10) Interpretation of the result of hypothesis testing

Interpreting study result analysis is doing interpretation to the hypothesis test. Interpretation and hypothesis test can be explained as follows:

a. Interpersonal communication skill toward BJBS employees' performance

The first hypothesis test with t-test shows that $\mathrm{t}$ count value 3.611 is accepted in the significance level of $5 \%(p<0.05)$. It means interpersonal skill has the positive and significant influence to BJBS employees' performance. The better the interpersonal communication skill is, the better the performance is. Likewise, the worse the interpersonal communication skill is, the worse the performance is.

Based on the table 4.14, the result of multiple regression analysis can be formulated into the following equation.

Yv a+b-X, = -3.869+0.325 X,

Where

$\mathrm{Y}=$ the BJBS employees' performance

$\mathrm{X}=$ interpersonal communication

From this equation, it can be determined that the employees' performance is influenced by their interpersonal skill with the following explanation:

1. The constant value is -3869 ; it means that if there is no increase in interpersonal communication skill, the employees' performance score decreases as much as 3.869 unit.

2. The regression coefficient value of interpersonal communication skill is 0.315 ; it means that if there is an increase in interpersonal communication skill for 1 unit, the employees' performance score will increase as much as 0.315 unit.

The result of this study supports the hypothesis that interpersonal communication skill significantly and positively influences the BJBS employees' performance.

b. Work motivation toward BJBS employees' performance

The first hypothesis test result with t-test shows that the value of t count of 3.106 is accepted on the significance level of $5 \%$ $(\mathrm{p}<0.05)$. It means that work motivation positively and significantly influences BJBS employees' performance. The better the motivation is, the better the performance is. Likewise, the worse the performance is, the worse the performance is.

Based on the multiple linear regression, the equation is as follows.

$\mathrm{Y}=\mathrm{a}+\mathrm{b}_{2} \mathrm{X}_{2}=-3.869+0.236 . \mathrm{X} 2$

Where:

$\mathrm{Y}=$ BJBS employees' performance

$\mathrm{X}_{2}=$ work motivation

The equation above shows that the employees' performance is influenced by work motivation with the following explanation:

1. The constant value is -3.869 ; it means that if there is no increase in the work motivation, the employees' performance score will decrease as much as 3.869 unit.

2. The regression coefficient value of work motivation is 0.236 ; it means that if there is an increase in the work motivation as much as 1 unit, the employee performance will drop as much as 0.315 unit.

The result of this study supports the hypothesis that work motivation positively and significantly to BJBS marketing employees' performance.

c. Interpersonal communication skill and work motivation toward BJBS employees' performance

The first hypothesis test using $\mathrm{F}$ tests shows that $\mathrm{F}$ count is 63.057. By comparing $\mathrm{F}$ count and $\mathrm{F}$ table, it was obtained that the value of $F$ count $>F$ table $(63.057>4.171)$. Thus, Ho is rejected. It means that interpersonal communication skill and work motivation simultaneously influence BJBS employees' performance. The better the interpersonal communication skill and work motivation, the better the performance. Likewise, the worse the interpersonal skill and work motivation, the worse the employees' performance.

Based on the table 4.14 the result of multiple regression analysis, the regression equation is as follows;

$Y=a+b_{1} X_{1}+b_{2} X_{2}=-3,869+0,31 S . x,+0,236 . x_{2}$

Where:

$\mathrm{Y}=\mathrm{BJBS}$ employees' performance

$\mathrm{X},=$ interpersonal communication skill

$\mathrm{X}_{2}=$ work motivation

The equation shows that the employees' performance is influenced by interpersonal skill and work motivation with the following explanation.

1. The constant value of -3.869 ; it means if there is no increase in interpersonal communication skill and work motivation, the employees' performance score decreases as much as 3.869 units. 
2. Regression coefficient value of interpersonal communication skill is 0.315 ; it means if there is an increase in interpersonal skill for 1 unit, the employee performance will increase 0.315 unit.

3. Regression coefficient value of work motivation is -0236; it means that if there is an increase in the work motivation for 1 unit, the employees' performance will increase for 0.236 unit.

The analysis shows that the coefficient value of determinant $R_{2}$ is 0.808 (detail calculation in Appendix 13). It can be concluded that the result of the test is a good fit. It shows that $80.8 \%$ variation of employees' work can be explained by interpersonal communication skill and work motivation. While only $19.2 \%$ of others can be explained by another variable outside the model. The study supports the hypothesis that interpersonal communication skill and work motivation positively and significantly influence BJBS employees' performance.

\section{Conclusion}

Based on the analysis and discussion, it can be concluded that:

a. Interpersonal communication skill positively and significantly influences BJBS employees' performance. It means interpersonal communication skills positively and [10] significantly influence BJBS employees' performance.

b. Work motivation positively and significantly affect BJBS employees' performance. It means that work motivation positively and significantly influences BJBS employees' performance.

c. Interpersonal communication skill and work motivation should be a strategy to increase the market share of BJBS because it has a strong influence as much as 80.8 percent to the performance of BJBS marketing employees.

\section{References}

[1] Benson BJ. Domain of Competence: Interpersonal and Communication Skills. Academic Pediatrics. 2014;14:S55-S65.

[2] Petrovici A, Dobrescu T. The role of emotional intelligence in building interpersonal communication skills. Procedia - Social and Behavioral Sciences. 2014;116:1405-10.

[3] Bozionelos N, Singh SK. The relationship of emotional intelligence with task and contextual performance: More than it meets the linear eye. Personality and Individual Differences. 2017;116:206-11.

[4] Jogaratnam G. How organizational culture influences market orientation and business performance in the restaurant industry. Journal of Hospitality and Tourism Management. 2017;31:211-9.

[5] Sidorova T. The social and psychological determinants of faculty members' work motivation. Procedia - Social and Behavioral Sciences. 2015;186:1188-91.

[6] Taguchi Y. Factors forming work motivation in japan. Procedia Manufacturing. 2015;3:717-22

[7] Colquitt L, Wesson. Organizational Behavior. Toronto: McGrawHill International; 2009.

[8] Valero D, Hirschi A. Latent profiles of work motivation in adolescents in relation to work expectations, goal engagement, and changes in work experiences. Journal of Vocational Behavior. 2016;93:67-80

[9] Björklund C, Jensen I, Lohela-Karlsson M. Is a change in work motivation related to a change in mental well-being? Journal of Vocational Behavior. 2013:83:571-80.

Nadirov O, Aliyev K. Motivation to work, labor income taxes and life satisfaction: Hungary, estonia, continental europe and the united states. Procedia Economics and Finance. 2016;39:373-9.

[11] Furiady O, Kurnia R. The effect of work experiences, competency, motivation, accountability and objectivity towards audit quality. Procedia - Social and Behavioral Sciences. 2015;211:328-35.

[12] George J, Jones G. Understanding and Managing Organizational Behavior. New Jersey: Prentice Hall; 2005.

[13] Lau PYY, Tong JLYT, Lien BY-H, Hsu Y-C, Chong CL. Ethical work climate, employee commitment and proactive customer service performance: Test of the mediating effects of organizational politics. Journal of Retailing and Consumer Services. 2017;35:20-6. 